\title{
A STUDY ON CUSTOMER'S PERCEPTION ABOUT ONLINE TRADING
}

\author{
L. PRABHA ${ }^{1}$, P. RAJSHREE ${ }^{2}$, A. SHARUNYA ${ }^{3} \&$ B. SRIDHANYA ${ }^{4}$ \\ ${ }^{1}$ Assistant Professor, Department of Commerce (PA), PSGR Krishnammal College for Women, \\ Coimbatore, Tamil Nadu, India \\ ${ }^{2,3,4}$ III B.Com (PA), PSGR Krishnammal College for Women, Coimbatore, Tamil Nadu, India
}

\begin{abstract}
Online trading is the act of purchasing and selling financial products on the Internet. The trader buys and sells using an online trading platform. Through online trading an investor can make sound decisions to increase profitability and the cost of online trading is lower compared to traditional physical trading. Online trading is a democratic medium. It gives the retail customer ready access to the market. The investor is in complete control of his investments and gets the benefits of transacting in real time. This paper aims to study about the customer's perception about online trading. KEYWORDS: Online Trading, Demat, Perception, Investors \& Faster Transactions
\end{abstract}

Received: Jan 22, 2019; Accepted: Feb 12, 2019; Published: Feb 25, 2019; Paper Id.: IJECRJUN20191

\section{INTRODUCTION}

\section{“An Investment in Knowledge Pays the Best Interest.” - Benjamin Franklin}

The use of online trading increased dramatically in the mid - to - late-90's with the introduction of affordable high-speed computers and internet connections. Stocks, bonds, mutual funds, options, EFT's, futures, and currencies can all be traded online. Online trading account offers feasibility to investors as it is simple, stable and fast to deploy. It enables investors to track movements of tradable assets and securities on a real-time basis. It gives the investors a gist of transactions, real-time quotes, and provides research tools and technical analysis, thus enabling them to make better trading decisions. The main benefit of an online trading account is the ease with which the investors can manage their stock portfolios without middlemen/brokers. It also gives them greater control to trust their own intuitions and take risks with their investments. Besides, the speed of transactions increases as everything can be done instantaneously

\subsection{Statement of the Problem}

Though online trading has several benefits, all business owners and customers find themselves challenged by a variety of factors almost every day and this is no different for online traders. Some of these problems relate to no patience on entry into trading, selling the assets too soon, letting small losses grow big, trading low probability opportunities, overtrading, hesitation, letting winners turn into losers etc. as this is a trending problem among customers doing online trading. An analysis of the above has been done through direct communication with some customers doing online trading and jotting down some important problems faced. 


\subsection{Objectives}

- To identify the customer's ranking on problems faced in online trading.

- To analyse the perception level of investors who trade online.

\subsection{Research Methodology}

\section{Methods Used for Data Collection}

- Primary data.

- Secondary data.

Tools Used for Analysis

- Percentage analysis

- Chi-square test

\subsection{Limitations of the Study}

- This study is limited to the questionnaire issued, these results may vary if the data is procured through secondary data.

- A detailed analysis cannot be made due to time constraints.

\section{REVIEW OF LITERATURE}

Professor Aadil Bade ${ }^{1}$ (2017), Department of Commerce, analyses about Demat account and online trading in his article published in the Scholarly Research Journal for Interdisciplinary studies. In his article, “Analysis- Demat account and online trading", he says that in India, Online trading is still at its infancy stage. But online trading has made it easy to trade in the stock exchange as now people can trade while sitting at their home.

Petric Loana Ancuta ${ }^{2}$ (2015), Explains that the investment and financial services companies should guide their marketing campaign to attract more investors for online platforms by studying other factors that influence the decision to move from traditional to online trading. He also says that the investors will switch to online trading when they have a high level of knowledge in the stock market, higher education and knowledge of internet.

A. Abdhul Rahim ${ }^{3}$ (2013), Has explained about SEBI and NSE, Where NSE trade securities online as per the regulation of SEBI. The author further discussed about the various difficulties faced by users of online trading and some of them includes computer literacy, poor infrastructure etc. He also added the benefits of investing in equities or equity oriented mutual funds for a longer period in his study.

\section{AN OVERVIEW OF ONLINE TRADING}

The rapidly advancing technology, particularly the Internet, has drastically changed the social and economic landscapes and every aspect of our daily lives. In the securities industry, the Internet has facilitated on-line trading, changing the way the market works, as well as the way the investors access the market. Stock exchanges worldwide now conduct a bulk of their business online through brokers and partners. In developed countries, almost all exchange transactions are conducted online. The trend has slowly picked up in India and two of the largest exchanges, the National 
Stock Exchange (NSE) and the Bombay Stock Exchange (BSE) have been conducting online trade successfully.

\subsection{Benefits of Online Trading}

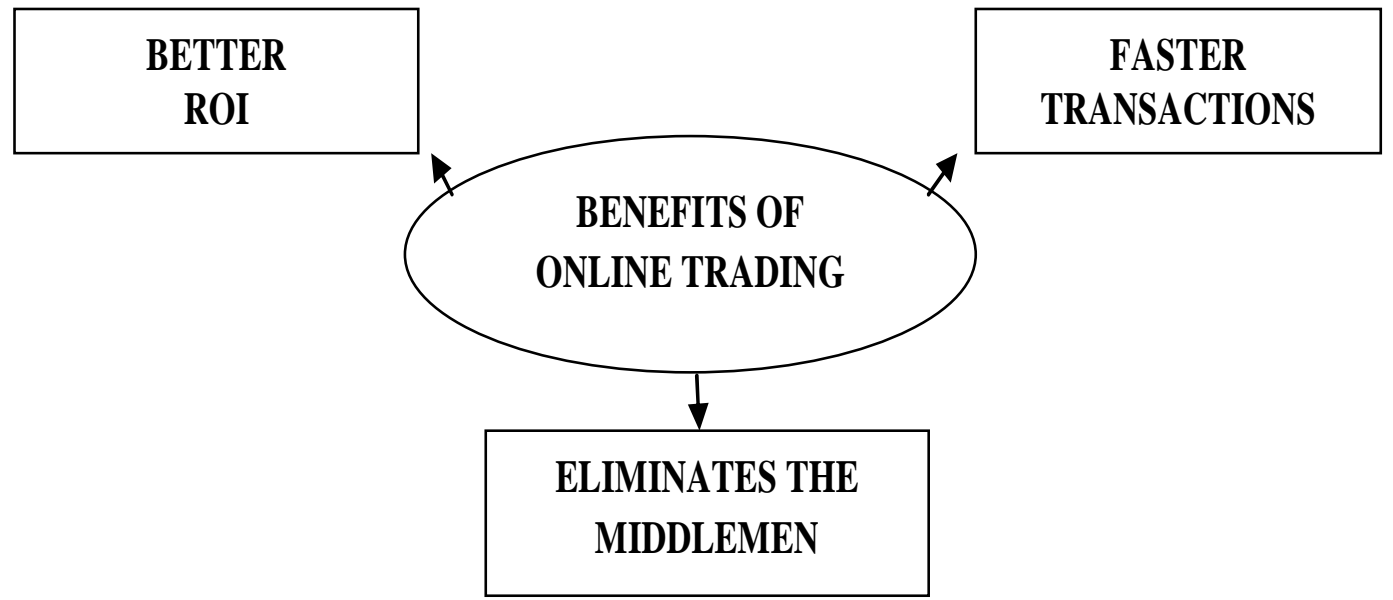

\section{ANALYIS OF DATA}

\subsection{Annual Savings of the Respondents}

\begin{tabular}{|c|l|c|c|}
\hline S. No & $\begin{array}{c}\text { Savings Per } \\
\text { Annum }\end{array}$ & $\begin{array}{c}\text { No. of } \\
\text { Resondents }\end{array}$ & Percentage \\
\hline 1 & Below 25000 & 36 & 29 \\
\hline 2 & $25001-50000$ & 25 & 20 \\
\hline 3 & $50001-75000$ & 25 & 20 \\
\hline 4 & Above 75000 & 39 & 31 \\
\hline & TOTAL & $\mathbf{1 2 5}$ & $\mathbf{1 0 0}$ \\
\hline
\end{tabular}

All the respondents have savings habits. Majority of the respondents save above Rs.75000.

\subsection{Perception Level of Online Customers}

\begin{tabular}{|c|l|c|c|c|c|c|c|}
\hline \multirow{2}{*}{ S. No } & \multirow{2}{*}{ Perception Level } & \multicolumn{2}{|c|}{ Very Good } & \multicolumn{2}{|c|}{ Good } & \multicolumn{2}{c|}{ Poor } \\
\cline { 3 - 7 } & $\begin{array}{c}\text { No. of } \\
\text { Respondents }\end{array}$ & $\%$ & $\begin{array}{c}\text { No. of } \\
\text { Respondents }\end{array}$ & $\%$ & $\begin{array}{c}\text { No. of } \\
\text { Respondents }\end{array}$ & $\%$ \\
\hline 1 & $\begin{array}{l}\text { Helpline-desk customer } \\
\text { relationship management }\end{array}$ & 46 & 36 & 67 & 54 & 12 & 10 \\
\hline 2 & $\begin{array}{l}\text { Reliability and } \\
\text { accessibility of support } \\
\text { services }\end{array}$ & 40 & 32 & 65 & 52 & 20 & 16 \\
\hline
\end{tabular}

\section{Helpline-Desk Customer Relationship Management}

The above table clearly explains that $36 \%$ of the respondents finds the helpline-desk customer relationship management as very good.

\section{Reliability and Accessibility of Support Services}

The above table clearly explains that $32 \%$ of the respondents finds the reliability and accessibility of support services as very good. 


\subsection{DP Holder's Problem}

\begin{tabular}{|c|l|c|c|}
\hline S. No & \multicolumn{1}{|c|}{ DP Holder's Problems } & Score & Rank \\
\hline 1 & Demat charges are too high & 639 & I \\
\hline 2 & Delay in demat of shares & 561 & II \\
\hline 3 & Unauthorised debit/credit to account & 493 & IV \\
\hline 4 & Non-dispatch of holding & 509 & III \\
\hline 5 & Delay in refund and remission of dividend & 432 & VI \\
\hline 6 & Loss of certifications in transit & 423 & VII \\
\hline 7 & Mutilation of certificates & 450 & V \\
\hline
\end{tabular}

The majority of the respondents has chosen high demat charges as their major problem and loss of certificates in transit is considered as the least problem by the customer.

\subsection{Savings \& Helpline-Desk Customer Relationship}

\section{Two Way Table}

\begin{tabular}{|c|c|c|c|c|}
\hline Savings & Very Good & Good & Poor & Total \\
\hline $25001-50000$ & $4(9)$ & $18(27)$ & $3(25)$ & 25 \\
\hline $50001-75000$ & $10(22)$ & $12(18)$ & $3(25)$ & 25 \\
\hline ABOVE 75000 & $20(43)$ & $17(25)$ & $2(17)$ & 39 \\
\hline Total & $\mathbf{4 6}$ & $\mathbf{6 7}$ & $\mathbf{1 2}$ & $\mathbf{1 2 5}$ \\
\hline
\end{tabular}

The perception level of the respondents for helpline-desk customer relationship when compared with savings was found very good with the highest percentage of 43 among the saving level above 75000 and the lowest percentage of 9 among the saving level between 25001-50000. The perception level of the respondents for helpline-desk customer relationship when compared with savings was found good with the highest percentage of 30 among the saving level below 25000 and lowest percentage of 18 among the saving level between 50001 - 75000. The perception level of the respondents for helpline-desk customer relationship when compared with saving was found poor with the highest percentage 33 of among the saving level below 25000 and the lowest percentage of 17 among the saving level above 75000 .

\section{Savings \& Helpline Desk Customer Relationship}

In order to find out the relationship between savings of the respondents and the perception level for helpline-desk customer relationship, Chi square test is used and the result of the test given below. The savings of the respondents and the perception level for helpline-desk customer relationship were tested with the help of following hypothesis.

\section{Chi-Square Test}

\begin{tabular}{|c|c|c|c|c|}
\hline Factors & $\begin{array}{c}\text { Calculated } \\
\text { Value }\end{array}$ & $\begin{array}{c}\text { Table } \\
\text { Value }\end{array}$ & $\begin{array}{c}\text { Degree of } \\
\text { Freedom }\end{array}$ & $\begin{array}{c}\text { Significant } \\
\text { Value }\end{array}$ \\
\hline SAVINGS & 9.614 & 12.592 & 6 & $5 \%$ \\
\hline
\end{tabular}

Since the calculated value is less than the table value, and the result is significant at $5 \%$ level. Hence, the H1 hypothesis is rejected and it is concluded that the savings of the respondents and the perception level for helpline desk customer relationship are independent. 


\subsection{Savings \& Reliability and Accessability of Support Services}

\section{Two Way Table}

\begin{tabular}{|c|c|c|c|c|}
\hline Savings & Very Good & Good & Poor & Total \\
\hline BELOW 25000 & $13(32)$ & $17(26)$ & $6(30)$ & 36 \\
\hline $25001-50000$ & $2(5)$ & $18(28)$ & $5(25)$ & 25 \\
\hline $50001-75000$ & $7(18)$ & $14(21)$ & $4(20)$ & 25 \\
\hline ABOVE 75000 & $18(45)$ & $16(25)$ & $5(25)$ & 39 \\
\hline Total & $\mathbf{4 0}$ & $\mathbf{6 5}$ & $\mathbf{2 0}$ & $\mathbf{1 2 5}$ \\
\hline
\end{tabular}

The perception level of the respondents for reliability and accessibility of support services when compared with savings was found as very good with the highest percentage of 45 among the saving level above 75000 and the lowest percentage of 5 among the saving level between 25001-50000. The perception level of the respondents for reliability and accessibility of support services when compared with savings was found good with the highest percentage of 28 among the saving level 25001-50000 and the lowest percentage of 21 among the saving level between 50001 - 75000. The perception level of the respondents for reliability and accessibility of support services when compared with saving was found poor with the highest percentage 30 of among the saving level below 25000 and the lowest percentage of 20 among the saving level between $50001-75000$.

\section{Savings \& Reliability and Accessibility of Support Services}

In order to find out the relationship between savings of the respondents and the perception level for reliability and accessibility of support services, Chi square test is used and the result of the test given below. The savings of the respondents and the perception level for reliability and accessibility of support services were tested with the help of following hypothesis.

\section{Chi-Square Test}

\begin{tabular}{|c|c|c|c|c|}
\hline Factors & $\begin{array}{c}\text { Calculated } \\
\text { Value }\end{array}$ & $\begin{array}{c}\text { Table } \\
\text { Value }\end{array}$ & $\begin{array}{c}\text { Degree of } \\
\text { Freedom }\end{array}$ & $\begin{array}{c}\text { Significant } \\
\text { Value }\end{array}$ \\
\hline SAVINGS & 10.3397 & 12.592 & 6 & $5 \%$ \\
\hline
\end{tabular}

Since the calculated value is less than the table value, and the result is significant at $5 \%$ level. Hence, the H1 hypothesis is rejected and it is concluded that the savings of the respondents and the perception level for reliability and accessibility of support services are independent.

\section{FINDINGS OF THE STUDY}

- The majority of the respondents finds that the perception level for helpline-desk customer relationship management reliability and accessibility of support services as good.

- The majority of the DP holders has chosen high demat charges as their major problem and loss of certificates in transit is considered as the least problem by the customer.

- The chi-square test shows that the savings of the respondents and the perception level for helpline-desk customer relationship and reliability and accessibility of support services is independent as the level is significant at $5 \%$. 


\section{SUGGESTIONS}

- The investors feel that the demat charges are too high, so the SEBI can consider to reduce the applicable securities transaction taxes which can improve substantial volume and help small investors to trade and invest. So lesser taxes and duties will as well attract more investments from mutual funds, large corporate brokers and private equity funds which will flow to our Indian bourses.

- To reduce delay in demat of shares, processing time should be to the minimum so as the end investors will be able to trade in a favourable market more faster and also delay on account on information technology should be controlled for effective process of demat.

\section{CONCLUSIONS}

The world is moving speed at the rate of thought. Security transactions need actions at the spur of the moment which is possible only in an online trading platform. Also, online services should offer customers a splendid display of benefits such as enhanced control and reduced transaction charges. It is also delightful to note that the investors are eager to be updated about the market situations. If the following factors are considered in the on-going trend, the infrastructure for online share trading will improve in future and there would be hike in volume of share trading.

\section{REFERENCES}

1. Professor Aadil Bade, (2017), “Analysis-Demat account and online trading”, An International peer reviewed \& Referred Scholarly research journal for interdisciplinary studies, Volume:4, Issue: 4, 2017, ISSN NO:2278-8808.

2. PetricLoanaAncuta,Annals of faculty of economic, University of Oradea, Faculty of economics, (2015), "Benefits and Drawbacks of online trading versus traditional trading. Educational factors in online trading”, volume:1 Pages:1253-1259 Issue:7, 2015.

3. Punekar, S., \& Gopal, R. (2016). A Study to Identify Customer's Online Apparel Shopping Behavior in Relation to Return Policies of E-Commerce Businesses, WR To Pune Region, India.

4. A. Abdhul Rahim, (2013), "Problems and prospects of online share trading practices in India", International journal of Marketing, Financial services \& Management research, Volume: 2,Issue: 15th May 2013, ISSN NO: 2277-3622

5. Trading systems and methods by Perry J. Kaufman

6. The intelligent investor by Benjamin Graham.

7. https://www.investopedia.com/articles/trading/11/automated-trading-systems.asp

8. http://www.academia.edu/33171514/ANALYSIS_DEMAT_ACCOUNT_AND_ONLINE_TRADING

9. https://www.omicsonline.org/open-access/online-trading-the-future-of-stock-market-2162-6359-1000271.php?aid=57190 